\title{
Viability and development of 'tube-locked' mouse embryos
}

\author{
M. M. Singh, V. Wadhwa, N. Sethi* and V. P. Kamboj \\ Division of Endocrinology and ${ }^{*}$ Division of Toxicology \& Experimental Medicine, \\ Central Drug Research Institute, Lucknow - 226001 , India
}

\begin{abstract}
Summary. 'Tube-locked' morulae and blastocysts were recovered from the ampulla of the oviduct of centchroman-treated mice between Days 4 and 12 post coitum and transferred to the uteri of pseudopregnant female mice. Pregnancy and implantation rates were lower and the post-implantation resorption rate was higher in the treated than in the control group. There was little difference in the pregnancy or implantation rates between embryos recovered on Days 4 or 12 post coitum, but the resorption rate increased with increasing duration of embryos in the oviducts and was $100 \%$ for the Day-12 embryos. The resorption rate was similar even when these embryos were transferred to the sterile uterine horn of unilaterally pregnant mice. Centchroman did not produce any deleterious effect on embryos which survived until Day 19 of pregnancy in foster mothers. The average fetal weight was also comparable to those of control fetuses.
\end{abstract}

\section{Introduction}

Centchroman (3,4-trans-2,2-dimethyl-3-phenyl-4-p ( $\beta$-pyrrolidinoethoxy phenyl)-7-methoxy chroman), a non-steroidal contraceptive being developed at this Institute, has been reported to induce 'tube-locking' of embryos at the ampullary-isthmic junction of the oviducts in mice, when administered within $24 \mathrm{~h}$ of mating. The compound, however, did not seem to produce any deleterious effect on preimplantation embryonic development, except for some delay in cleavage rate, morula to blastocyst transformation and shedding of zona pellucida. Apparently normal embryos were recovered from the ampulla of centchroman-treated mice until Day 10 post coitum (Singh \& Kamboj, 1981). We have now investigated the viability and development of embryos 'tube-locked' after treatment with centchroman by surgical transfer of embryos recovered at different times to the uteri of untreated pseudopregnant females or to the sterile horn of unilaterally pregnant mice.

It is generally believed that preimplantation mammalian embryos are remarkably resistant to teratogens and after treatment during this period either die before implantation or survive to term without being malformed (Austin, 1973). Earlier investigators have stressed the need for teratological evaluation of new compounds by treatment during the preimplantation period in addition to the conventional treatment during the period of organogenesis. In view of this, and the suggestion that the 'tube-locked' embryos might ultimately migrate to the uterus and implant (Humphrey, 1976), the 'tube-locked' embryos developing until Day 19 of pregnancy in the foster mothers were assessed for any teratological anomalies. 


\section{Materials and Methods}

Colony bred adult Swiss mice $(20-30 \mathrm{~g})$ of this Institute were maintained in air-conditioned quarters $\left(22 \pm 1^{\circ} \mathrm{C}\right)$ and in uniform husbandry conditions. The animals were kept in cages in groups of 5 and were given pellet diet (Hindustan Levers Ltd, Bombay) and tap water ad libitum.

Donor females mated to fertile male mice received one oral dose of $2 \mathrm{mg}$ centchroman $/ \mathrm{kg}$ body weight (Singh \& Kamboj, 1981) or the vehicle (distilled water) alone, within $24 \mathrm{~h}$ of mating. The day of mating was designated Day 1 . Untreated females mated to adult vasectomized males served as recipients. The males had been bilaterally vasectomized at least 6 weeks earlier and their sterility was confirmed by matings to adult females of proven fertility. Donor mice were killed at 08:00$10: 00 \mathrm{~h}$ for the recovery of embryos.

Morulae and blastocysts were flushed from the oviducts and uteri of untreated control mice, and the oviducts of centchroman-treated mice by means of a blunt 30-gauge needle attached to a 1-ml glass syringe and warm $\left(37^{\circ} \mathrm{C}\right)$ sterile BMOC-2 medium (Cross \& Brinster, 1970), according to the procedure described earlier (Singh \& Kamboj, 1981). The medium was prepared before use with chemicals purchased from Sigma, St Louis, Missouri, U.S.A. and sterilized by passing through a sterile Millipore filter (pore size $0.45 \mu \mathrm{m}$ ). The $\mathrm{pH}$ of the medium was adjusted to about 7.4 with sterile $5 \% \mathrm{CO}_{2}$ in air. The embryos were washed $2-3$ times with sterile medium before transfer. The required numbers of embryos were picked up in $0.2-0.5 \mu \mathrm{l}$ of the medium, using a sterile glass micropipette attached to a $1 \mathrm{ml}$ glass syringe through a small rubber tubing, and gently transferred into each uterine horn of an untreated pseudopregnant female through a small puncture made near its distal end with a sterile 24 -gauge needle. When embryos were transferred into the sterile uterine horn of unilaterally pregnant mice, one uterine horn of each recipient had been ligated and incised near the uterotubal junction on Day 1 post coitum. In our experience, such mice do not normally exhibit implantations in the ligated horn. On average 4 embryos were transferred into each uterine horn. All manipulations were carried out under sterile conditions. The details of the numbers and age of the embryos transferred and of the recipients used are shown in Tables $1 \& 2$.

The recipients were laparotomized on Day 10 post coitum and the numbers of normal and resorbed implantation sites were recorded. Animals with apparently normal implantation site(s) were kept and the fetuses were delivered by Caesarian section on Day 19 of pregnancy. Each fetus was weighed and examined for gross defects. Some of the fetuses were fixed in Bouin's solution and examined for visceral abnormalities by the sectioning method of Wilson (1964), while others were cleared in $1 \% \mathrm{KOH}$ solution and stained by Dawson's Alizarin Red technique (Sethi, 1977) for visualization of any skeletal defects.

The $2 \times 2$ contingency test (Fisher's exact test or $\chi^{2}$ approximations) was applied for statistical evaluation of the differences in the pregnancy, implantation and resorption rates between the control and the centchroman-treated groups. Fetal weights were compared by Student's $t$ test.

\section{Results}

About $80 \%$ of the pseudopregnant recipient female mice became pregnant after surgical transfer of embryos recovered from control mice on Days 4 and 5 of pregnancy. However, only about $40 \%$ of the 203 transferred embryos implanted in the foster mothers. Of these, about $13 \%$ showed signs of resorption by Day 10, but the rest developed normally until Day 19 of pregnancy (Tables 1 \& 2 ). Statistically, there was no significant difference in the pregnancy, implantation or resorption rates for the embryos donated and received on Days 4 and 5 post coitum.

When 'tube-locked' embryos recovered from centchroman-treated mice between Days 4 and 12 post coitum were transferred to the uteri of pseudopregnant female mice on Days 4 or 5 post coitum, there was a significant reduction $(P<0.001)$ in the pregnancy $(35 \%)$ and implantation $(15 \%)$ rates and an elevation $(P<0.001)$ of the post-implantation resorption rate $(71 \%$, Tables $1 \& 2)$. There 


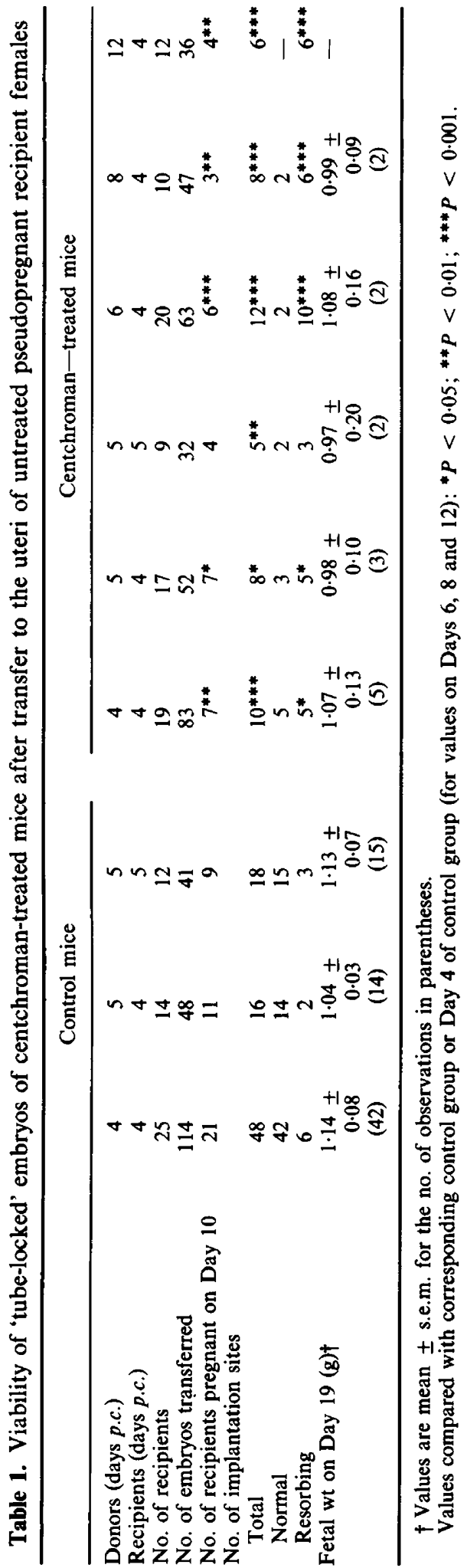


Table 2. Viability of 'tube-locked' embryos of centchroman-treated mice after transfer to the uteri of untreated pseudopregnant or unilaterally pregnant recipient females

\begin{tabular}{|c|c|c|c|c|}
\hline & \multicolumn{2}{|c|}{ Pseudopregnant recipients } & \multicolumn{2}{|c|}{$\begin{array}{c}\text { Unilaterally } \\
\text { pregnant recipients }\end{array}$} \\
\hline & Control & Centchroman & Control & Centchroman \\
\hline Donors (days p.c.) & $4-5$ & 4-12 & $4-5$ & $4-12$ \\
\hline Recipients (days p.c.) & 4-5 & 4-5 & 4-5 & 4-5 \\
\hline No. of recipients & 51 & 87 & 25 & 57 \\
\hline No. of embryos transferred & 203 & 313 & 105 & 220 \\
\hline \multicolumn{5}{|c|}{ No. of recipients pregnant on Day 10} \\
\hline Intact side & & & $25(100 \%)$ & $57(100 \%)$ \\
\hline Transferred side & $41(80 \%)$ & $31(35 \%)^{* * *}$ & $20(80 \%)$ & $22(39 \%)^{* *}$ \\
\hline \multicolumn{5}{|c|}{$\begin{array}{l}\text { No. of implantations on Day } 10 \\
\text { Intact side }\end{array}$} \\
\hline Total & & & 86 & 244 \\
\hline Normal & & & 84 & 243 \\
\hline Resorbing & & & $2(2 \%)$ & $1(0.4 \%)$ \\
\hline \multicolumn{5}{|l|}{ Transferred side } \\
\hline Total & $82(40 \%)$ & $49(15 \%)^{* * *}$ & $50(48 \%)$ & $37(17 \%)^{* *}$ \\
\hline Normal & 71 & 14 & 47 & 12 \\
\hline Resorbing & $11(13 \%)$ & $35(71 \%)^{* * *}$ & $3(6 \%)$ & $25(68 \%)^{* *}$ \\
\hline Fetal wt on Day $19(\mathrm{~g}) \dagger$ & $1 \cdot 14 \pm 0.08$ & $1.07 \pm 0.13$ & - & $-\ddagger$ \\
\hline
\end{tabular}

$\dagger$ Values are mean \pm s.e.m. for the no. of observations in parentheses.

$\ddagger$ Not recorded.

Values significantly different from control group: ${ }^{* *} P<0.01 ;{ }^{* * *} P<0.001$.

was no significant difference in the pregnancy or implantation rates between embryos donated on Days $4(36.8$ and $12.0 \%)$ and $12(33.3 \%$ and $16.7 \%$, respectively), but the resorption rate showed a marked rise with increasing duration of the embryos in the oviducts $(50,60,83,75$ and $100 \%$ for Days 4, 5, 6, 8 and 12 post coitum respectively: Days $4+5$ versus Days $6+7+8 ; P<0.05$ ). The resorption rate remained high when embryos from centchroman-treated mice were transferred to the sterile uterine horn of unilaterally pregnant mice (Table 2).

None of the 14 embryos that were alive at Day 19 of pregnancy and delivered by Caesarian section had any gross or skeletal abnormalities. The average weight of these fetuses $(1.07 \mathrm{~g})$ was comparable to that of transferred embryos of control mice $(1 \cdot 14 \mathrm{~g})$ or of normally pregnant females $(1.09 \mathrm{~g})$.

\section{Discussion}

These results show that centchroman did affect the viability of mouse embryos. Little information is available in the literature on the viability and development of embryos 'tube-locked' in the ampulla by treatment with oestrogenic/antioestrogenic compounds. Viability of 'tube-locked' embryos recovered from oestradiol-treated mice on Day 4 post coitum was not affected (Humphrey, 1968) but there is no information for embryos retained in the ampulla for longer periods.

Blastocysts confined within the oviduct beyond Day 6 of pregnancy by placing a ligature at the utero-tubal junction failed to develop when transferred to the uteri of untreated pseudopregnant mice (Weitlauf, 1971). In contrast, in the present study at least $17 \%$ of the embryos 'tube-locked' until Day 8 post coitum implanted when transferred to the uterus of suitable recipients; and $25 \%$ of these developed normally to healthy fetuses. This difference might be due to the different sites of confinement of the embryos in the oviducts. In the centchroman-treated mice the embryos are always retained in the ampullary portion (Singh \& Kamboj, 1981); but in ligated tubes, they 
migrate to proximal portion (loop 8) of the isthmus (Humphrey, 1968), and this is not a site conducive to normal preimplantation embryonic development (Whittingham, 1968). Moreover, while an apparent delay in cleavage rate, morula to blastocyst transformation and shedding of zona pellucida has been demonstrated for embryos 'tube-locked' in response to oestrogenic compounds (Humphrey \& Martin, 1968; Humphrey, 1968; Singh \& Kamboj, 1981), no such delay in development was observed when embryos were retained in the oviducts by ligation (Humphrey \& Martin, 1968). In contrast, embryos recovered from ligated oviducts have been reported to possess relatively high metabolic activity (Weitlauf, 1971). Whether the dormant condition of the "tubelocked' embryos of centchroman-treated mice in any way protects them from damage, as has been suggested for the dormant uterine embryos of mice undergoing experimentally induced delay of implantation (Weitlauf, 1971), is, however, not known. Pertinently, the diapausing uterine blastocysts of mouse have been reported to remain viable for as long as 25 days (Weitlauf \& Greenwald, 1968).

It is important to determine whether the depressed pregnancy and implantation rates and the increased resorption rate observed after transfer of the 'tube-locked' embryos in this study were due only to their proionged confinement in the ampulla or were associated with a direct effect of the compound on the embryos. It is not known whether compounds like centchroman actually enter the lumen of the genital tract in quantities sufficient to affect embryonic development. In the rat, in which 'tube-locking' of the embryos does not occur (Blye, 1970), centchroman induces a situation akin to delayed implantation and the embryos, which remain in utero in a viable condition, implant after exogenous oestrogen and progesterone treatment (Kamboj, Setty, Chandra, Roy \& Kar, 1977). This, and the implantation and development to healthy fetuses of 'tube-locked' embryos after transfer to foster mothers observed in this study, suggests that centchroman acts by alteration of genital tract function and not by a direct cytotoxic effect. Embryos recovered from rats treated with certain other non-steroidal antioestrogens, such as tamoxifen (Walpole, 1968), clomiphene (Staples, 1966), U-11100A and U-11555A (Duncan \& Forbes, 1965), retain the ability to develop in foster mothers. The different effect of centchroman in mice needs be to investigated in rats. The tests with unilaterally pregnant recipient mice in this study demonstrated that the post-implantation resorption of embryos from centchroman-treated females is not due to the lack of a sustained luteotrophic stimulus. It is well established that, in the mouse, ovaries are required throughout the period of gestation (Rubinstein \& Forbes, 1963).

Centchroman administered to pregnant mice and rabbits during the period of organogenesis does not cause any congenital anomalies (Sethi, 1977), and the normality of those embryos that did develop from mice treated with centchroman during the preimplantation stages is encouraging.

We thank Dr Nitya Nand for his keen interest in this study; Mr S. K. Mathur for assistance in evaluation of the fetuses for teratogenicity and $\mathrm{Mr} \mathrm{P}$. A. George for statistical analysis. This study received financial assistance from the Ministry of Health and Family Welfare, Government of India. V.W. is a CSIR Senior Research Fellow, and this is Paper no. 3135 of the C.D.R.I.

\section{References}

Austin, C.R. (1973) Embryo transfer and sensitivity to teratogens. Nature Lond. 244, 333-334.

Blye, R.P. (1970) The effect of estrogens and related substances on embryonic viability. Adv. Biosci. 4, 323342.

Cross, P.C. \& Brinster, R.L. (1970) In-vitro development of mouse oocytes. Biol. Reprod. 3, 298-307.

Duncan, G.W. \& Forbes, A.D. (1965) Blastocyst survival and nidation in rats treated with oestrogen antagonists. J. Reprod. Fert. 10, 161-167.

Humphrey, K. \& Martin, L. (1968) Effect of oestrogen and anti-oestrogens on ovum transport in mice. $J$. Reprod. Fert. 15, 191-197.

Humphrey, K.W. (1968) The effects of oestradiol-3,17 on tubal transport in the laboratory mouse. J. Endocr. 42, 17-26.

Humphrey, K.W. (1976) Influence of estrogen and progesterone on oviductal function. In Ovum Transport and Fertility Regulation, pp. 495-505. Eds M. J. K. Harper, C. J. Pauerstein, C. E. Adams, E. M. Coutinho, H. B. Croxatto \& D. M. Paton. Scriptor, Copenhagen. 
Kamboj, V. P., Setty, B. S., Chandra, H., Roy, S. K. \& Kar, A. B. (1977) Biological profile of centchromana new post-coital contraceptive. Indian J. exp. Biol. 15, 1144-1150.

Rubinstein, P. \& Forbes, T.R. (1963) Maintenance of pregnancy with subcutaneous pellets of progesterone in ovariectomized mice. Proc. Soc. exp. Biol. Med. 113, 1043-1046.

Sethi, N. (1977) Influence of centchroman on prenatal development in mice and rabbits. Indian J. exp. Biol. 15, $1182-1183$.

Singh, M.M. \& Kamboj, V.P. (1981) Effect of centchroman on pre-implantation embryonic development and tubal transport in mice. Biol. Reprod. 25, 171-181.

Staples, R.E. (1966) The effect of clomiphene on blastocyst nidation in the rat. Endocrinology 78, 82-86.
Walpole, A.L. (1968) Nonsteroidal drugs in relation to ovulation and implantation. J. Reprod. Fert., Suppl.4, 3-14.

Weitlauf, H.M. (1971) Protein synthesis by blastocysts in the uteri and oviduct of intact and hypophysectomized mice. J. exp. Zool. 176, 35-40.

Weitlauf, H.M. \& Greenwald, G.S. (1968) Survival of blastocysts in the uteri of ovariectomized mice. $J$. Reprod. Fert. 17, 515-520.

Whittingham, D.G. (1968) Development of zygotes in cultured mouse oviduct. I. Effect of varying oviductal conditions. J. exp. Zool. 169, 391-397.

Wilson, J.G. (1964) Methods for administering agents and detecting malformations in experimental animals. In Teratology Principles and Techniques, pp. 262-277. Eds J. G. Wilson \& J. Warkany. University of Chicago Press.

Received 9 September 1982 